\title{
OUTSOURCING WORKERS IN THE FORM OF A SUBSIDIARY
}

\author{
Eva ŠANTAVÁ ${ }^{1,3}$, Benjamin SCHMACHER ${ }^{2,3}$, \\ Viktória TALNAGIOVÁ ${ }^{1,3}$, Jozef SABLIK ${ }^{3}$ \\ ${ }^{1}$ OSRAM, A.S. KOMÁRŇANSKÁ CESTA 7, 94093 NOVÉ ZÁMKY, SLOVAK REPUBLIC \\ ${ }^{2}$ SMS AUSTRIA GMBH, SMS-STRAßE 1, 9065 EBENTHAL IN KÄRNTEN, AuSTRIA \\ ${ }^{3}$ SLOVAK UNIVERSITY OF TECHNOLOGY IN BRATISLAVA \\ FACULTY OF MATERIALS SCIENCE AND TECHNOLOGY IN TRNAVA \\ INSTITUTE OF INDUSTRIAL ENGINEERING AND MANAGEMENT \\ Ulica JÁNA BotTu 2781/25, 91724 TRNAVA, SLOVAK REPUBLIC \\ e-mail: eva.santava@stuba.sk, benjamin.schmacher@stuba.sk, \\ qtalnagiova@stuba.sk,jozef.sablik@stuba.sk \\ Received 15 April 2020, accepted 04 June 2020, published 25 June 2020
}

\begin{abstract}
Many production companies have fully adopted a lean management philosophy, but their finances and control departments also need to adapt to this trend. All departments must adapt to the changing requirements and reflect the new challenges in production management. The controlling has undergone a lot of changes. Downloading data is no longer the only task of a controller. Controlling can be integrated into the organizational structure of the company internally as well as externally. Our goal is to define the advantages and disadvantages of using an internal or external controller. To decide whether to outsource some of the process is not just a question of cost reduction or time reduction. Companies very often decide for outsourcing in case of processes, which require special "know how" or are key from the competitiveness point of view. Outsourcing therefore represents a strategic change. Cost savings are only a side effect.
\end{abstract}

\section{Key words}

Outsourcing, controlling, process improvement, efficiency, criteria, internal controller, external controller

\section{INTRODUCTION}

The current situation in the business environment comprises ever-increasing competition, which creates pressure on the company management. In order to withstand this complex and demanding situation, it is necessary for the management to have the right information that leads to timely and quality decisions. Higher and higher requirements and expectations are placed on the company's employees. To be able to increase or even to maintain the company's 
profitability, it is necessary to improve the planning, control and management of the company. It is important to find out the deviations from the plan in time, otherwise the management is no table to take a stand to the deviation. Management must be prepared for implementation of the measures which will lead to elimination of deviations to the plan. If the company constantly fits the deviations between reality and the plan, and it is not able to eliminate these deviations in the long run, it is the right time to outsource these processes.

\section{OUTSOURCING WORKERS IN THE FORM OF A SUBSIDIARY}

As a result of the economic crisis, many companies deal with problems related to decreasing customer demand. Companies are looking for a solution, the quickest way is optimizing the cost and reducing the number of their own employees. In advanced economies, in times of recession, the effort is dominated by a more effective way of managing businesses, which will demonstrate ways of potential cost savings, while maintaining the subject of its main activity. Such modern management methods include controlling, outsourcing, benchmarking, re-egineering and many others [3].

The decision to include controlling within the company largely depends on the size of the company. If it is small, the function of controller is taken over by the business owner. For larger ones, it is customary to set up a special controlling department, which supervises accounting and reporting, prepares reports and documents for decision-making to the company's management. The form of an internal controller has its advantages and disadvantages [1].

Outsourcing is hiring of another company or individual outside of your own company to manage various business processes and activities. This is done instead of using an internal team or individuals. In a world where all businesses are under increasing pressure to reduce costs and increase performance, outsourcing is becoming an increasingly strategic choice [6].

Outsourcing represents a significant intervention in the company's activities and a meeting of two cultures. This brings less visible problems, which mean, however, greater risk for the success of the outsourcing relationship [5].

As part of monitoring overall productivity and company-wide performance, it is necessary to focus on such areas and monitor such financial indicators that have the highest added value in terms of controlling. For controllers to be able to assess which processes are important to outsource, it is necessary to have a good information and communication system. Creation and maintenance of the information and communication system security are also often transferred to an external specialist. By outsourcing the IT processes, we could achieve better and more efficient data flow, information and knowledge. This is the alpha \& omega of the controlling system. The reports prepared by controlling department should be the heart of every information system. The right data is important when deciding for financial indicators, planning their target values, subsequent monitoring, process measurement, reporting and solving identified deviations. Provided information should not be unnoticed, they should lead to the adoption and implementation of the measures aimed at eliminating the weaknesses and anomalies. One of the main tasks of outsourcing is to improve the processes that the company has decided to outsource.

Controlling plays an important role in identifying the processes and scope of activities that are appropriate to be transferred to external specialists. In order to achieve successful transfer of the process to outsourcing company, it is necessary to provide external specialists all necessary and detailed information. Controlling department has a perfect overview of individual processes, their efficiency and financial indicators. The controllers, in cooperation with the company's management, apply outsourcing for the continuous running of controlling functions and for the improvement of the monitored "problem" processes and indicators. The information obtained by the controlling department is therefore the basis for the subsequent 
decision-making of the company's management regarding which processes make sense to outsource, as from the controlling point of view the operation is inefficient. Even if the processes are outsourced, they still need to be part of the controlling scope and still be managed internally by the company. Before the company's management decides whether and which process needs to be outsourced, it is necessary to consider the economic advantage of its transfer to external specialists. Entrustment to external specialists is the optimal choice if the company is not able to ensure the planned state even the internal experts try to implement several changes in the given processes with no success. Therefore, outsourcing should be the last possible solution to improve processes.

Empirical research has been conducted on the basis of information on the role of controlling in outsourcing. Its main objective was to define the advantages and disadvantages of an internal and external controller. In the framework of research, we approached 10 production companies within the electrotechnical industry with a number of employees over 250 , with foreign participation. The choice of sampling within the category of large companies assumed that large companies have greater precondition for outsourcing owing to a significantly larger number of processes. The research was conducted through a questionnaire with closed questions related to outsourcing within controlling. The possibility of answers ranged from:

1 - maximization value - the greatest importance

8 - minimization value - the lowest importance

We used a multi-criteria comparison to evaluate the questions. Based on the comparison, we obtained point evaluation within the individual criteria.

The questions were defined as follows:

1. Organize the individual criteria based on their significance in your company in terms of:

How is controlling covered in your company within internal resources?

An overview of the individual criteria that were the subject of the arrangement is shown in Table 1.

\begin{tabular}{|c|c|c|c|c|c|c|c|c|}
\hline \multicolumn{1}{|c|}{ Table 1 } & Criteria overview. Source: own processing \\
\hline & $\mathbf{K 1}$ & $\mathbf{K} 2$ & $\mathbf{K 3}$ & $\mathbf{K} 4$ & $\mathbf{K 5}$ & $\mathbf{K 6}$ & $\mathbf{K} 7$ & $\mathbf{K 8}$ \\
\hline Criteria & $\begin{array}{c}\text { knowledge of } \\
\text { the company } \\
\text { and its } \\
\text { processes }\end{array}$ & cost saving & $\begin{array}{c}\text { streamlining } \\
\text { business } \\
\text { activities }\end{array}$ & $\begin{array}{c}\text { direct } \\
\text { coordination } \\
\text { of the } \\
\text { company's } \\
\text { activities }\end{array}$ & $\begin{array}{c}\text { qualification } \\
\text { of workers }\end{array}$ & $\begin{array}{c}\text { updating } \\
\text { work skills }\end{array}$ & $\begin{array}{c}\text { education } \\
\text { within the } \\
\text { field }\end{array}$ & $\begin{array}{c}\text { imminent } \\
\text { conflict of } \\
\text { interest }\end{array}$ \\
\hline average rating & $\mathbf{1 , 3}$ & $\mathbf{2 , 4}$ & $\mathbf{3 , 6}$ & $\mathbf{2 , 6}$ & $\mathbf{5 , 4}$ & $\mathbf{7 , 2}$ & $\mathbf{5 , 6}$ & $\mathbf{7 , 8}$ \\
\hline
\end{tabular}

2. Organize the individual criteria based on their significance in your company in terms of:

How is controlling covered in your company within external resources?

An overview of the individual criteria that were the subject of the arrangement is shown in Table 2.

\begin{tabular}{|c|c|c|c|c|c|c|c|c|}
\hline Table 2 & Criteria overview. Source: own processing \\
\hline & $\mathbf{K 1}$ & $\mathbf{K 2}$ & $\mathbf{K 3}$ & $\mathbf{K 4}$ & $\mathbf{K 5}$ & $\mathbf{K 6}$ & $\mathbf{K 7}$ & $\mathbf{K 8}$ \\
\hline Criteria & $\begin{array}{c}\text { creativity and } \\
\text { innovation in } \\
\text { business } \\
\text { processes }\end{array}$ & $\begin{array}{c}\text { acquiring new } \\
\text { ways to } \\
\text { reduce costs }\end{array}$ & $\begin{array}{c}\text { prepared } \\
\text { detailed } \\
\text { working } \\
\text { documentatio } \\
\text { n with a clear }\end{array}$ & $\begin{array}{c}\text { easy } \\
\text { substitutability } \\
\text { within the staff }\end{array}$ & $\begin{array}{c}\text { delivery of } \\
\text { professional } \\
\text { advice on } \\
\text { request } \\
\text { timely, clear } \\
\text { and } \\
\text { transparent } \\
\text { reports }\end{array}$ & $\begin{array}{c}\text { overseeing } \\
\text { compliance } \\
\text { with policies } \\
\text { and } \\
\text { procedures in }\end{array}$ & $\begin{array}{c}\text { ensuring } \\
\text { higher quality } \\
\text { of delivered } \\
\text { data }\end{array}$ \\
\hline average rating & $\mathbf{5 , 4}$ & $\mathbf{3}$ & $\mathbf{7 , 2}$ & $\mathbf{2 , 2}$ & $\mathbf{1 , 8}$ & $\mathbf{5 , 5}$ & $\mathbf{6 , 6}$ & $\mathbf{4 , 2}$ \\
\hline
\end{tabular}


Following reasons have been considered as main advantages of using an internal controller [1]:

- knowledge of the company and its processes,

- cost savings compared to outsourced controlling,

- streamlining business activities at all levels,

- direct coordination of the company's activities and a clear link between the company's past, present and future.

Following reasons have been considered as main disadvantages of using an internal controller [1]:

- insufficient qualification of employees,

- insufficient education within the field,

- insufficient updating of work skills,

- insufficient experience,

- emergence of conflicts between the controller and the company's management due to a conflict of interest.

Following reasons have been considered as main advantages of using an external controller [2]:

- creativity and innovation in business processes,

- creativity and innovation in decision-making,

- acquiring new ways how to reduce costs,

- acquisition of new expertise,

- there is no need for such supervision over the work of the controller,

- elaborated detailed working documentation with a clear procedure of individual processes,

- easy substitution within the staff,

- professional advice on request,

- delivery of timely, clear and transparent reports,

- overseeing compliance with policies and procedures in processes,

- ensuring higher quality of delivered data.

Following reasons have been considered as main disadvantages of using an external controller:

- loss of control over individual processes,

- communication problem due to distance,

- ignorance of the company,

- differences in location and time zone.

However, the services of an external controller do not meet the needs of all companies. There are reasons why management rejects the external power of the controller [4].

\section{CONCLUSIONS}

Every change in the process has its advantages and disadvantages. As each company is specific, it is necessary to define in its processes what is best for the company. If controlling identifies weaknesses in business processes that cannot be eliminated in any way in the long run, it is the right time to contact an external expert. We can state that companies usually outsource only certain processes that they could not cover by themselves. 
The inclusion of the controller within the organizational structure and the definition of his/her tasks depends on the size of the company. Large companies have several options. The role of the controller can be covered by the internal controller, then it is an internal form of controlling. The role of the controller can also be covered by an organization that deals with controlling through an external controller, which is an external form of controlling. In the case of big corporations, there is currently another possibility, which is also called outsourcing, but within the group. Within the group, processes can be outsourced by the centre of expertise or by the centre of shared services. The general goal of such a transformation is the same, to align financing with the company's overall strategy to become more efficient and provide better services to its internal customers. The transformation of controlling will be the subject of my further research.

\section{References}

\section{Book publishing:}

[1] ARWINGE, O. 2012. Internal COntrol: A Study of Concept and Themes. Berlin: Springer Science \& Business Media,

[2] BRAGG, S. M. 2012. The Essential Controller: An Introduction to What Financial Manager Must Know. New York: Wiley.

[3] POTKÁNY, M., HAJdUKOVÁ, A., TEPLICKÁ, K. 2012. Target Costing Calculation in the Woodworking Industry to Support Demant at the Time of Global Recession. Drewno Wood.

[4] TSAY, A. 2014. Designing and Controlling the Outsourced Supply Chain. Breda: New Publishers,

\section{Internet sources:}

[5] CFO. [cit. 2020-05-27]. Online on the Internet: http://www.cfo.sk/articles/najcastejsie-priciny-neuspechu-outsourcingovych projektov\#.Xs1b_eQUmhc

[6] LEINONEN. [cit. 2020-05-27]. Online on theInternet: https://leinonen.eu/group-en/group-articles/why-should-my-business-outsource-accountingservices 